\title{
Ligand-Induced Growth Cone Collapse: Amplification and Blockade by Variant GAP-43 Peptides
}

\author{
Michihiro Igarashi, ${ }^{a}$ Wei Wei Li, Yoshiaki Sudo, and Mark C. Fishman \\ Developmental Biology Laboratory and Cardiovascular Research Center, Massachusetts General Hospital, \\ Charlestown, Massachusetts 02129 and Department of Medicine, Harvard Medical School, Boston, \\ Massachusetts 02115
}

\begin{abstract}
Growth cones are powerful amplifiers for signals from the microenvironment. Their collapse can be triggered by cell surface components of myelin and brain membranes, as well as by soluble ligands, including neurotransmitters. GAP-43 is a protein concentrated on the inner surface of the growth cone membrane. Assayed in isolation, it interacts with the heterotrlmeric protein, $G_{o}$, and in oocytes it amplifies the effects of ligand-triggered $G$ protein activation. We wished to examine whether GAP-43 serves to amplify signals at the growth cone. The $G_{0}$ stimulating region of GAP-43 is encoded in the 10 amino acids (MLCCMRRT$K Q$ ) of the first exon. We examined the effect of this peptide upon chick dorsal root ganglion growth cone collapse and neurite retraction triggered by brain membranes or myelin, as well as by serotonin. We find that application of the GAP-43 1-10 peptide amplifies the effects of all three ligands. The amplification is greater when GAP-43 1-10 is injected intracellularly. Peptides with amino acid substitutions for the two cysteine residues manifest parallel changes in growth cone collapse and $G_{0}$ stimulation. In particular, tyrosine or methionine substitutions cause the peptide to inhibit $G_{0}$ and to block induced growth cone collapse. The GAP-43 peptides therefore regulate the sensitivity of growth cones to extrinsic signals. The modified peptides serve as a starting point for the design of reagents to enhance CNS regeneration.
\end{abstract}

[Key words: regeneration, nerve growth, myelin, G proteins, GAP-43, growth cone]

It has been suspected since the turn of the century (Ramon y Cajal, 1990), and proved more recently (David and Aguayo, 1981; Keynes and Cook, 1992; Johnson, 1993), that the constraints upon growth in the CNS are due chiefly to inhibitory signals, rather than to an intrinsic inability of mature neurons to grow. This is an important clinical issue because there are about 3 million individuals paralyzed from CNS trauma or disease and there is no cure. Included among the inhibitory influences are components of CNS myelin (Caroni and Schwab, 1988) and

\footnotetext{
Received Jan. 20, 1995; revised April 4, 1995; accepted April 6, 1995.

M.I. is a recipient of an overseas fellowship from the Uehara Memorial Foundation.

Correspondence should be addressed to Dr. Mark C. Fishman, Developmental Biology Laboratory and Cardiovascular Research Center, Massachusetts General Hospital-East, 149 13th Street, 4th Floor, Charlestown, MA 02129.

aPresent address: Department of Molecular and Cellular Neurobiology, Gunma University School of Medicine, Maebashi, Gunma 371, Japan.

Copyright (C) 1995 Society for Neuroscience 0270-6474/95/155660-08\$05.00/0
}

activities associated with the surfaces of brain membranes (Raper and Kapfhammer, 1990). These factors can be assayed in vitro because they cause growth cone collapse, a feature that correlates with inhibition of nerve growth (Cox et al., 1990; Davies et al., 1990; Raper and Kapfhammer, 1990). In several cases, but probably not all, the collapse of growth cones involves $G$ proteins (Igarashi et al., 1993).

GAP-43 is a protein associated with the inner surface of growth cone membranes, and is believed to function in regulation of nerve growth and/or nerve terminal plasticity (Benowitz and Routtenberg, 1987; Skene, 1989; Strittmatter and Fishman, 1991). It has several functional domains, encoded in three exons. The first exon encodes a membrane binding and $G$ protein stimulating region (Zuber et al., 1989b; Strittmatter et al., 1990). The second exon includes a calmodulin binding site, unusual in that its affinity for calmodulin is reduced by increased calcium levels and by phosphorylation of an adjacent serine by protein kinase C ( $\Lambda$ lexander et al., 1987). The carboxy terminus has features that resemble neurofilament (LaBate and Skene, 1989), which is of interest because of GAP-43's interaction with the membrane skeleton (Meiri and Gordon-Weeks, 1990).

The cellular functions of GAP-43 are still debated. Its pattern of expression in developing (de la Monte et al., 1989), regenerating (Skene and Willard, 1981), and remodeling (Benowitz et al., 1988) neurons has led to speculation that it is related to neuronal growth and plasticity. When introduced into non-neural cells, it certainly can enhance certain surface features of the membrane, such as filopodial extension (Zuber et al., 1989a; Nielander et al., 1993; Widmer and Caroni, 1993), but whether it does so by affecting cytoskeletal motors or by altering sensory input from the cell's environment is unknown. Antibodies to GAP-43 reduce ligand-stimulated transmitter release (Dekker et al., 1989). Which domain of GAP-43 is related to which function is not clear.

Recently, we have found that GAP-43 can act to stimulate G proteins (Strittmatter et al., 1990, 1991). Injected into oocytes, GAP-43 enhances by manyfold the responsiveness to ligands for $\mathrm{G}$ protein-coupled receptors, suggesting that it interacts at the level of $\mathrm{G}$ proteins and their coupling to receptors (Strittmatter et al., 1993). In the context of the growth cone, it would be predicted that GAP-43 would amplify signals mediated by G proteins, and enhance collapse.

Peptides corresponding to the GAP-43 amino terminus enhance $\mathrm{G}$ protein activity, suggesting that this is the active domain of GAP-43 in this interaction (Strittmatter et al., 1990). Recently, we have found that these GAP-43 amino-terminal peptides add- 
ed extracellularly at micromolar concentrations to chick dorsal root ganglion neurons cause growth cone collapse (Strittmatter et al., 1994a). Although unresolved how or even whether such peptides permeate cells, cven longer peptides have been notcd previously to enter nerve cells and to affect nerve growth (Bloch-Gallego et al., 1993).

Here we have examined whether GAP-43 peptides amplify ligand-induced collapse. We find that at $10^{-8} \mathrm{M}$, concentrations far below those with evident effects by themselves, GAP-43 peptides markedly amplify the effects of inhibitory ligands, blocking neurite growth and increasing growth cone collapse. Even though native GAP-43 is intracellular, these peptides act when added to the medium, suggesting that they enter the cells. When injected intracellularly, they are even more effective. Certain modifications cause the peptide to interfere with the effects of inhibitors.

\section{Materials and Methods}

Cell culture assays. Chick DRGs from embryonic day 7 were explanted onto laminin-coated chamber slides in $F 12$ medium with $10 \mathrm{ng} / \mathrm{ml}$ nerve growth factor and 10\% fetal bovine serum. The GAP-43 1-10 peptide (MLCCMRRTKQ) was added into the culture medium at $10^{-8} \mathrm{M} 1 \mathrm{hr}$ prior to the addition of brain membrane extracts (BME). After $30 \mathrm{~min}$ incubation with inhibitors, the explant was fixed in glutaraldehyde and its growth cones were scored as collapsed or fan shaped (Igarashi et al., 1993). For culture of retina, chick E7 retina was cut into small pieces and explanted and assayed as described (Igarashi et al., 1993). For assays of neurite growth, chick E7 DRGs were trypsinized, triturated, plated on fibronectin-coated dishes for $2 \mathrm{hr}$ to remove non-neuronal cells, and then plated onto laminin-coated chamber slides in the presence of peptides or PBS. After $6 \mathrm{hr}$ of culture, cells were fixed by $1 \%$ glutaraldehyde in PBS, and the fraction of neurons with a process longer than $20 \mu \mathrm{m}$ was determined. Myelin proteins and brain membrane extracts were prepared and added to the culture medium as described by Igarashi et al. (Igarashi et al., 1993). 5-HT (Sigma) was added to the medium of DRG explants for $30 \mathrm{~min}$ at $37^{\circ} \mathrm{C}$. After fixation, the growth cones were analyzed, as above. In some experiments, ritanserin (RBI, Natick, MA), a 5- $\mathrm{HT}_{2}$-specific antagonist (Leysen et al., 1986), was added into the medium $30 \mathrm{~min}$ prior to 5 -HT at a 1:1 ratio with 5-HT.

Microinjection. Dissociated neurons from E9 or E10 chick DRGs were plated on chamber slides coated with poly-L-lysine and laminin and cultured for $3 \mathrm{hr}$. Single neurons were pressure injected with an Eppendorf microinjector. Micropipettes made from borosilicate capillaries were loaded with GAP-43 1-10 peptide dissolved in $0.1 \mathrm{M} \mathrm{KCl}$, and diluted to the desired concentration with $2.5 \%$ of the fluorescent tracer tetramethylrhodamine dextran (Molecular Probes). The peptide solutions were prepared fresh for each injection experiment. Neurons were incubated at $37^{\circ} \mathrm{C}$ for $30 \mathrm{~min}$ immediately after injection. Cells were counted 10-15 min after injection and reexamined 2 hr later. Neurons with neurites longer than the cell body diameter were considered ncurite positive. For each treatment, at least four separate experiments were performed and more than 200 neurons were injected.

\section{Results}

GAP-43 native peptide augments inhibitory responses to cell surface ligands

Brain membrane extracts (BME) from chick embryos cause chick dorsal root ganglion (DRG) and retinal growth cones to collapse in dose-dependent manners (Raper and Kapfhammer, 1990; Igarashi et al., 1993). As shown in Figure 1A, addition of the GAP-43 $1-10$ peptide at a concentration of $10^{-8} \mathrm{M}$ does not cause growth cone collapse. It does, however, enhance the response to BME. The collapse of retinal growth cones induced by $\mathrm{BME}$ also is potentiated by pretreatment with the GAP-43 $1-10$ peptide (Fig. $1 B$ ). As shown, in the presence of $10^{-8} \mathrm{M}$ GAP-43 1-10 peptide, the sensitivity of growth cones to BME (in terms of half-maximal response) is nearly doubled for DRG neurons and tripled for retinal neurons. The potentiation of re-
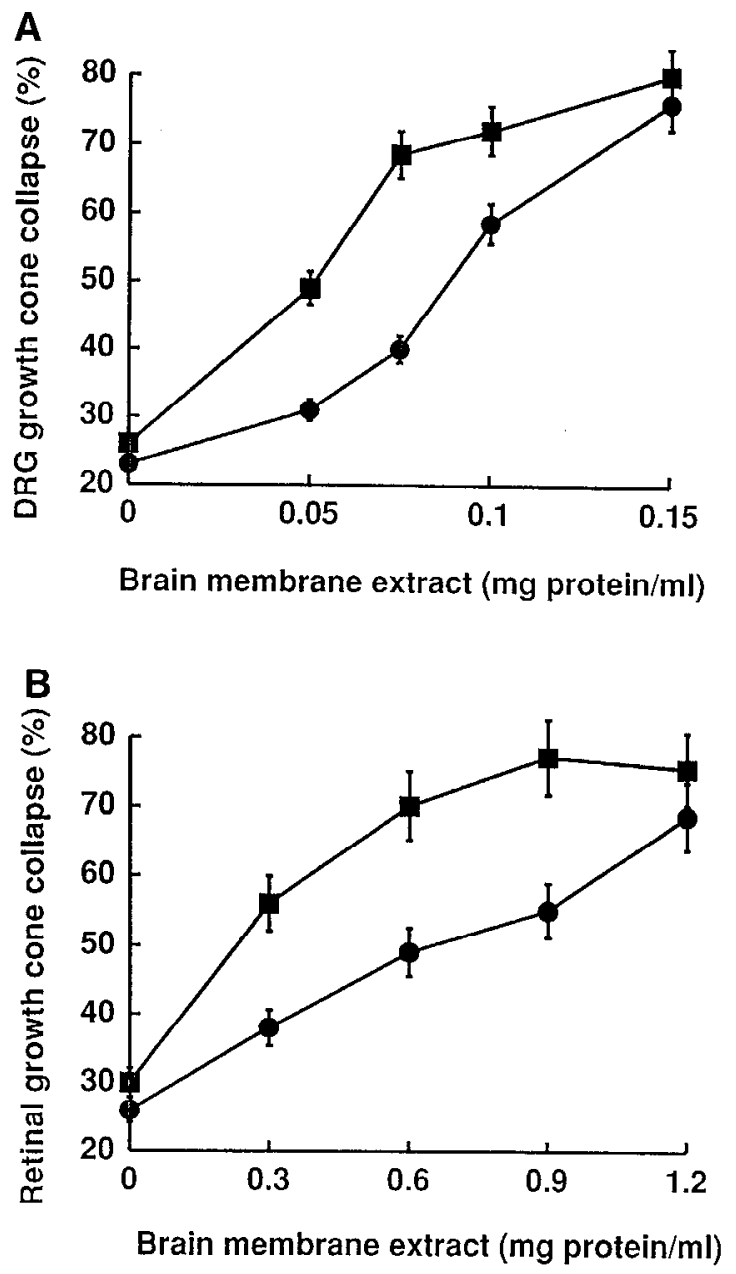

Figure 1. Synergistic interaction between inhibitors of neurite outgrowth and $10^{-8} \mathrm{M}$ of the GAP-43 1-10 N-terminus peptide. $A$ and $B$, Growth cone collapse in response to increasing concentration of brain membrane extract $(B M E)$ prepared from chick embryos. Chick dorsal root ganglion $(D R G)$ neurons $(A)$ and retinal neurons $(B)$ were cultured in the absence $(O)$ and presence $(\square)$ of the GAP-43 1-10 peptidc. The peptide itself does not affect the proportion of collapsed growth cones within the concentration range used here, but enhances the response of both types of neurons to BME. The values shown are the means \pm SEM for four separate experiments.

sponse to BME by the GAP-43 peptides is blocked by $20 \mathrm{ng} /$ $\mathrm{ml}$ pertussis toxin (PTX), showing that, like the collapse induced by higher BME concentrations, a PTX-sensitive G protein is involved (Igarashi et al., 1993). These data suggest that the GAP-43 peptides enhance collapse by amplifying $G$ protein stimulation by inhibitory ligands.

Components of myelin are believed to be especially important in halting neurite growth. CNS myelin proteins solubilized by octylglucoside also cause growth cone collapse, and are potentiated in their effect by the GAP-43 1-10 peptide (data not shown). We also examined the effects on neurite outgrowth, per se. As shown in Figure 2, myelin proteins inhibit nerve growth and low doses of the GAP-43 1-10 peptide potentiate the inhibition of neurite outgrowth.

\section{Intracellular injection of peptides}

Since GAP-43 is an intracellular protein, we presumed that these GAP-43 peptides exert their effects from within the cell. It is not clear by what mechanism peptides would enter the cell. Al- 


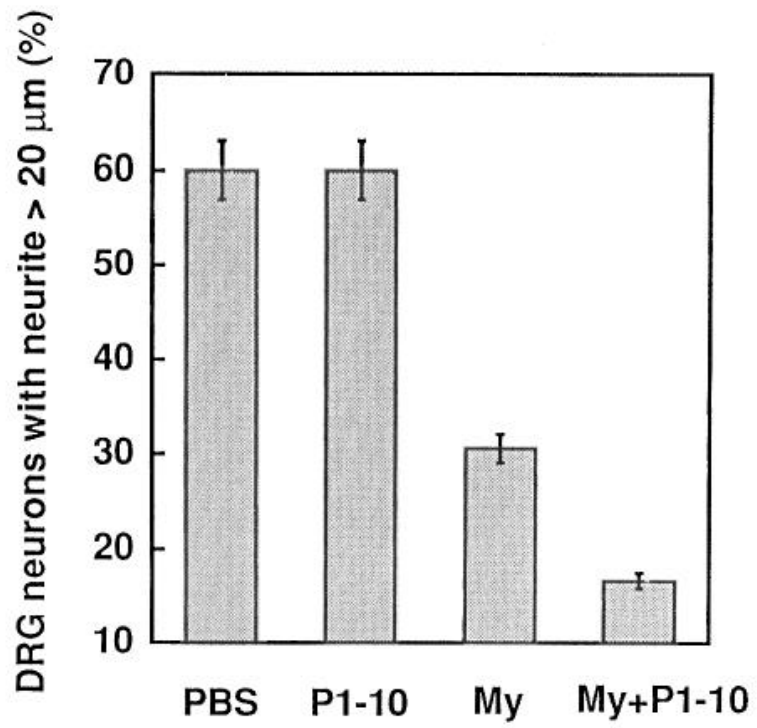

Figure 2. GAP-43 potentiates the inhibitory effect of solubilized myelin upon neurite outgrowth. Myelin proteins of adult rat CNS myelin $(M y)$, were solubilized by octylglucoside and dialyzed against F12 medium (Igarashi et al., 1993). PBS alone $(P B S)$ or the GAP-43 peptide alone $(P I-10)$ does not affect the fraction of DRG neurons with neurites longer than $20 \mathrm{~mm}$. The inhibitory effects of myelin $(M y)$ are potentiated by the pretreatment of neurons with $10^{-8} \mathrm{M} \mathrm{1-10}$ peptide ( $\mathrm{My}$; $+1-10)$. The values shown are the means \pm SEM for four separate experiments.

though the growth cone has very active vesicular uptake mechanisms, peptide exchange from within such vesicles has not been explored. However, it is known that other peptides can enter nerve cells, including mastoparan (Higashijima et al., 1990) and an Antennapedia homeobox polypeptide of 60 amino acids, the former of which blocks (Igarashi et al., 1993) and the latter of which enhances nerve growth (Bloch-Gallego et al., 1993).

To examine the intracellular effects directly, we introduced the GAP-43 peptide by intracellular injection. Cells needed to be isolated for injection, and growth cone morphology of the isolated neurons proved not to be predictable enough for quantitation, so we used the neurite length assay for these microinjection experiments. Injected rhodaminated dextran fills the entire cell and its neurites within 10-15 min and still reveals the neurites 2 hr later [Fig. 3, left panels, comparing a field immediately after injection (top) and $2 \mathrm{hr}$ later (bottom)]. After intracellular delivery of $10^{-8}$ or $10^{-10} \mathrm{M}$ peptide, the neurites are initially labelled (top panels) but withdraw after BME addition (bottom panels, middle and right). This is quantitated in Figure 4. As shown, at $10^{-10} \mathrm{M}$ the injected peptide had no significant effect, but combined with BME did cause retraction (Fig. 4). When applied extracellularly there also is a potentiation of BME-induced retraction, but less than after injection, as would be expected if the peptide acts within the cell.

\section{Peptides augment 5-HT-induced collapse}

Soluble factors, including neurotransmitters (Davenport et al., 1993), have been identified as important in directing (Kennedy et al., 1994) and retarding neuronal growth (Pini, 1993). In other species, serotonin (5-HT) causes growth cone collapse (Haydon et al., 1984) and downregulation of NCAM-like molecules and fasciculation (Peter et al., 1994). Serotonin receptors are present in many cells of the nervous system, including DRG (Ivgy-May et al., 1994). As shown in Figure 5A, 5-HT causes a dose-dependent growth cone collapse, with half-maximal effect at $10^{-4}$ M. As shown in Figure $5 B$, this effect is blocked by PTX and by the selective $5-\mathrm{HT}_{2}$ receptor antagonist ritanserin. In the presence of the GAP-43 peptide, the 5-HT dose-response curve

\section{Dye alone}
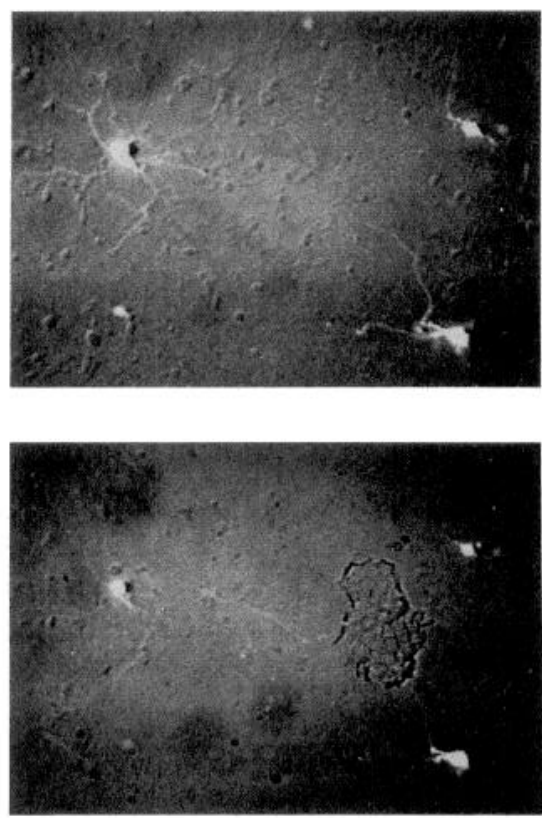

$10^{-8} \mathrm{M} \mathbf{P 1 - 1 0}+\mathrm{BME}$
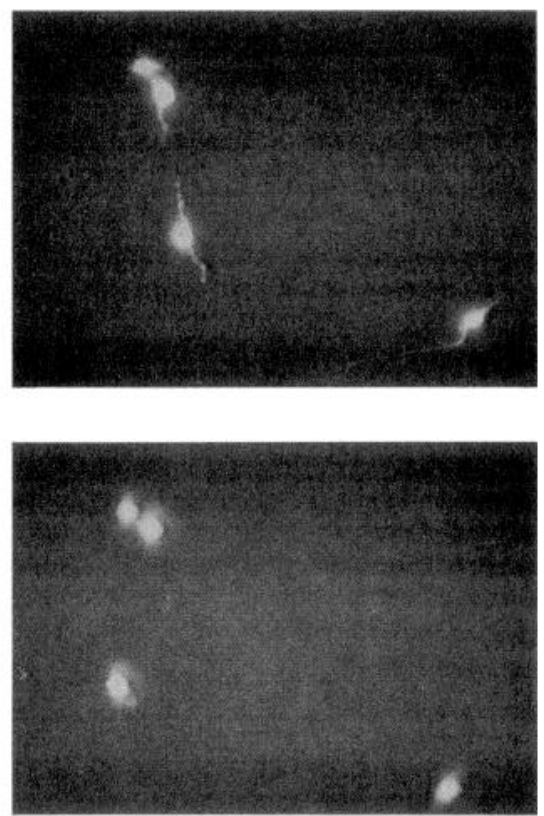

$10^{-10} \mathrm{M} P 1-10+\mathrm{BME}$
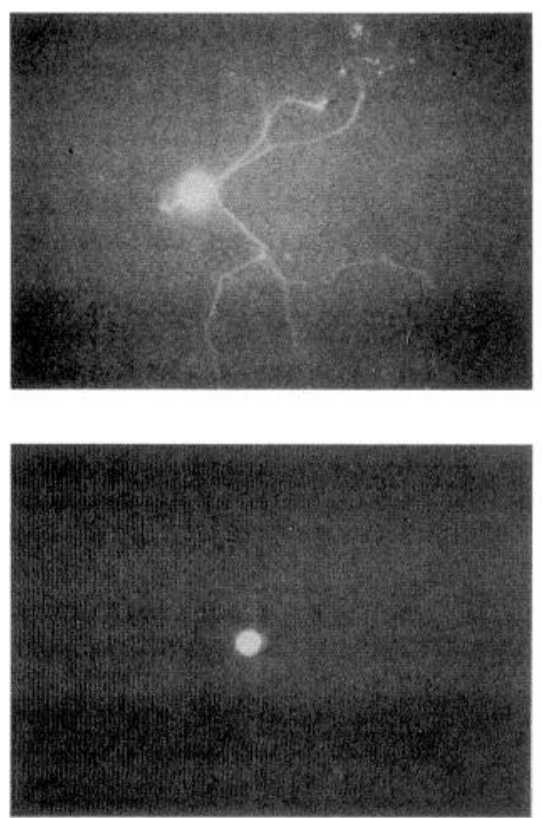

Figure 3. Intracellular action of the GAP-43 1-10 peptide. Intracellular delivery of GAP-43 1-10 peptide in the presence of BME causes neurite retraction of chick DRG neurons. The top panels show that injected cell have neurites immediately after injection with dye (left) $10^{-8} \mathrm{M} P 1-10$ (middle), or $10^{-10} \mathrm{M}(\mathrm{P} 1-10)$ (right). The bottom panels show the same cells $2 \mathrm{hr}$ later after BME addition to the medium, with neurites persisting in the dye-alone injected cells (left) but not in either of the peptide injected cells (middle and right). 


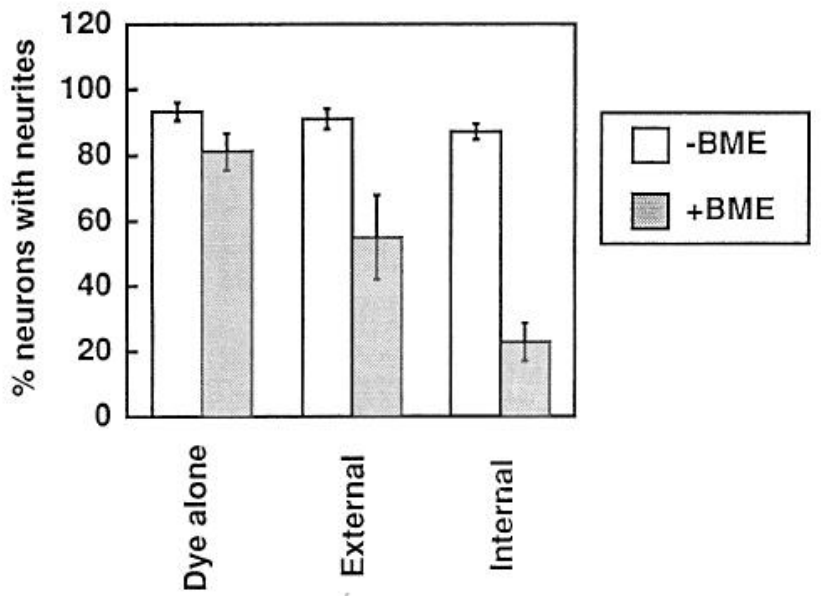

Figure 4. Quantitation of effects of intracellular peptide injection. Percent injected neurons with neurites after microinjected with dye alone, extracellular delivery of $10^{-10} \mathrm{M} \mathrm{P1-10} \mathrm{peptide,} \mathrm{or} \mathrm{intracellular} \mathrm{injection}$ with $10^{-10} \mathrm{M}$ P1-10 peptide in the absence (blank bar) or presence (hatched bar) of $0.2 \mathrm{mg} / \mathrm{ml}$ BME. For external 1-10 peptide application, neurons were incubated for 30 min immediately after injection, followed by application of peptides for $1 \mathrm{hr}$. Brain membrane extracts were added to the medium for $30 \mathrm{~min}$. For each treatment, at least four separate experiments were performed and more than 200 neurons were injected $(n=214$ dye, - BME; 232 dye, +BME; 227 external, - BME; 293 external, +BME; 206, internal, -BME; 227, internal, +BME) Data presented are the means \pm SEM. There is enhanced neurite retraction by peptides, and it is more with internal than with external application.

shifts to the left, indicating that the growth cone collapsing effect of 5-HT is markedly enhanced by the GAP-43 peptide (Fig. $5 A$ ). For example, as shown in Figure $5 C, 5-\mathrm{HT}$ at $10^{-5} \mathrm{M}$ has negligible effect, but is markedly enhanced by the peptide. This synergistic effect is blocked by PTX and by ritanserin (Fig. $5 C$ ), indicating that the GAP-43 effect is mediated via the $5-\mathrm{HT}_{2}$ receptor. Serotonin similarly reduces neurite outgrowth (Fig. $5 D$ ), and the GAP-43 1-10 peptide amplifies this inhibitory effect significantly, while ritanserin blocks it. This shows that GAP-43 1-10 amplifies signals transmitted via the $5-\mathrm{HT}_{2}$ receptor in nerves, as it does serotonin responses in injected oocytes (Strittmatter et al., 1993).

\section{Design of peptides to block inhibitory effects}

We wondered if GAP-43 peptides could be designed to interfere with, rather than enhance, the response to collapsing ligands. As a starting point, we took the observation that the cysteines are critical for $\mathrm{G}_{\mathrm{o}}$ stimulation (Sudo et al., 1992). We generated peptides with different amino acids substituted for the two cysteines. As shown in Figure $6 A$, most modifications render the peptide neutral with regard to G-protein stimulation. The substitutions with tyrosine (Y) or with methionine (M), however, generate peptides inhibitory for $\mathrm{G}_{0}$.

We examined whether these peptide modifications could affect the growth cone sensitivity to brain membrane extracts. Using concentrations of BME that cause maximal levels of collapse, the addition of either the $\mathrm{Y}$-substituted or M-substituted peptide reduces the degree of collapse from $75-80 \%$ to $50 \%$. Other peptides do not (Fig. 6B). The collapse caused by increasing concentrations of brain membrane extracts is shown in Figure $6 C$, in the presence of GAP-43 1-10 peptide, or the $\mathrm{M}$ or $\mathrm{Y}$ peptides, at doses of the peptides that do not have any evident effect by themselves. As shown in Figure 6, in the presence of $\mathrm{M}$ or $\mathrm{Y}$, the dose-response curve is shifted, so that about twice as much BME is needed to cause $50 \%$ collapse. Collapse at higher BME concentrations are likely to be $\mathrm{G}$ protein independent (Igarashi et al., 1993).

\section{Discussion}

Here we have shown that the decapeptide corresponding to the GAP-43 amino terminus, added exogenously to cultured neurons, enhances their responsiveness to growth-inhibitory ligands. These effects are even more potent when the peptide is injected, as expected if it exerts its action intracellularly, as does native GAP-43. By designing peptides with different amino acids replacing the two cysteines, residues that normally are subject to palmitoylation and crucial to GAP-43's activity, we found peptides that can inhibit ligand-induced growth cone collapse. These results are compatible with our suggestion that a function of GAP-43 is to amplify receptor-mediated signals at the growth cone.

\section{The amino-terminal domain of GAP-43}

Although widely speculated to be a "plasticity" protein, how GAP-43 might perform this role is ill-defined. It is enriched in most, if not all, growth cones during development and in adult CNS regions notable for their "plasticity" (Benowitz et al., 1988). It has been speculated to be necessary for axon elongation (Skene and Willard, 1981), growth cone shape (Zuber et al., 1989a), and neurotransmission (Dekker et al., 1989), as well as for signal transduction at the growth cone or synapse (Strittmatter et al., 1993). GAP-43 has several defined biochemical functions as an isolated protein. It binds calmodulin, with an affinity reduced by increasing ambient calcium and by PKC phosphorylation of a serine (at position 41) adjacent to the calmodulin-binding domain in exon 2 (Alexander et al., 1987). Thus, it has been proposed to serve as a calmodulin sink, releasing calmodulin in the wake of electrical activity when intracellular calcium is higher and PKC activity triggered (Alexander et al., 1987; Skene, 1989). Antibodies to the region including ser $^{41}$ reduce stimulated transmitter release (Dekker et al., 1989). The carboxy terminus, exon 3, has neurofilament-like regions (LaBate and Skene, 1989), which may contribute to GAP-43's interaction with the cytoskeleton (Meiri and Gordon-Weeks, 1990).

GAP-43 is likely to cause growth cone collapse by dint of its G-protein stimulation. Inside of a cell, at least an oocyte, GAP43 has two effects upon $G$ proteins (Strittmatter et al., 1993). At higher concentrations, it causes G-proteins activation; at lower ones, it has no evident effect by itself, but markedly amplifies the G-protein stimulation caused by ligands for G-protein-coupled receptors. Therefore, insofar as peptides mimic the action of the native protein, it would be predicted that high concentrations might cause G-protein stimulation, and, hence, growth cone collapse, which they do (Strittmatter et al., 1994); concentrations below those with evident effects might serve to amplify other G-protein-mediated signals received at the growth cone. As shown here, both for membrane-associated and soluble signals, that is exactly what the GAP-43 peptides do.

The amino terminus, corresponding to the coding region of exon 1, is crucial to membrane binding (Zuber et al., 1989b), and to G-protein stimulation (Strittmatter et al., 1990, 1994a,b). Both functions depend upon the two cysteines (Zuber et al., 1989b; Strittmatter et al., 1990), which are palmitoylated (Sudo et al., 1992), although how much GAP-43 is depalmitoylated under different situations is not clear. 
Fig. 5A
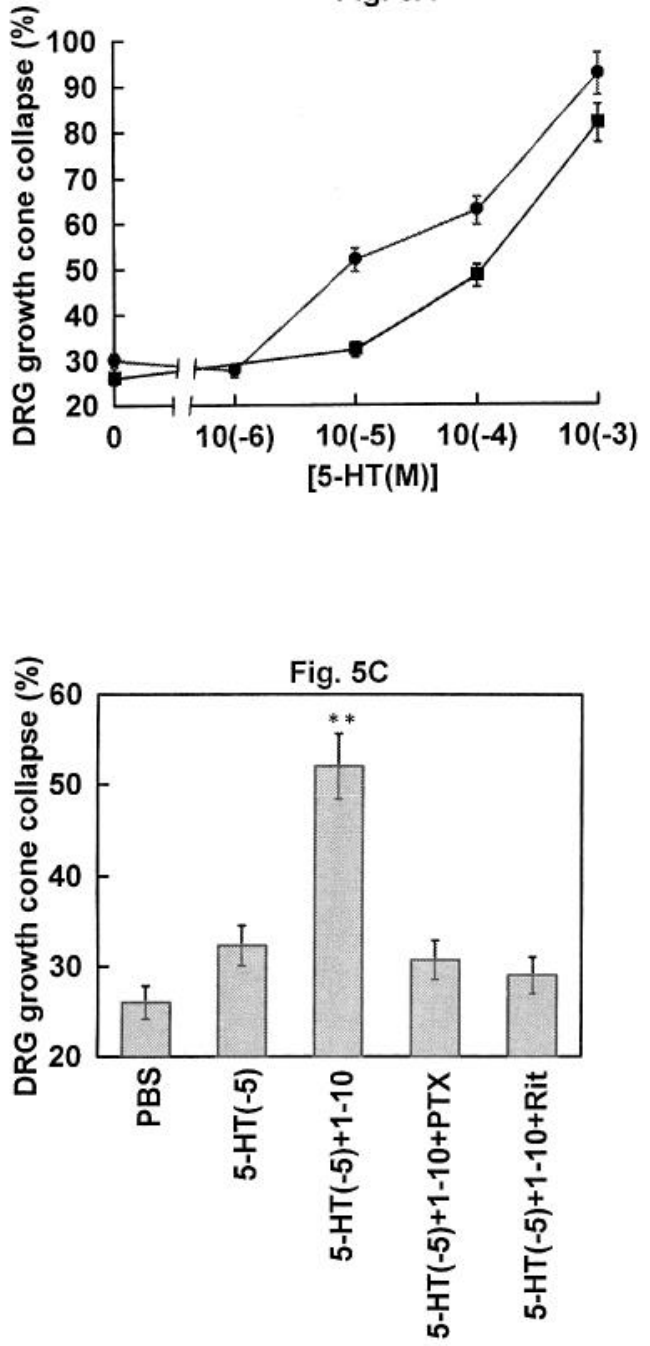

Fig. 5B
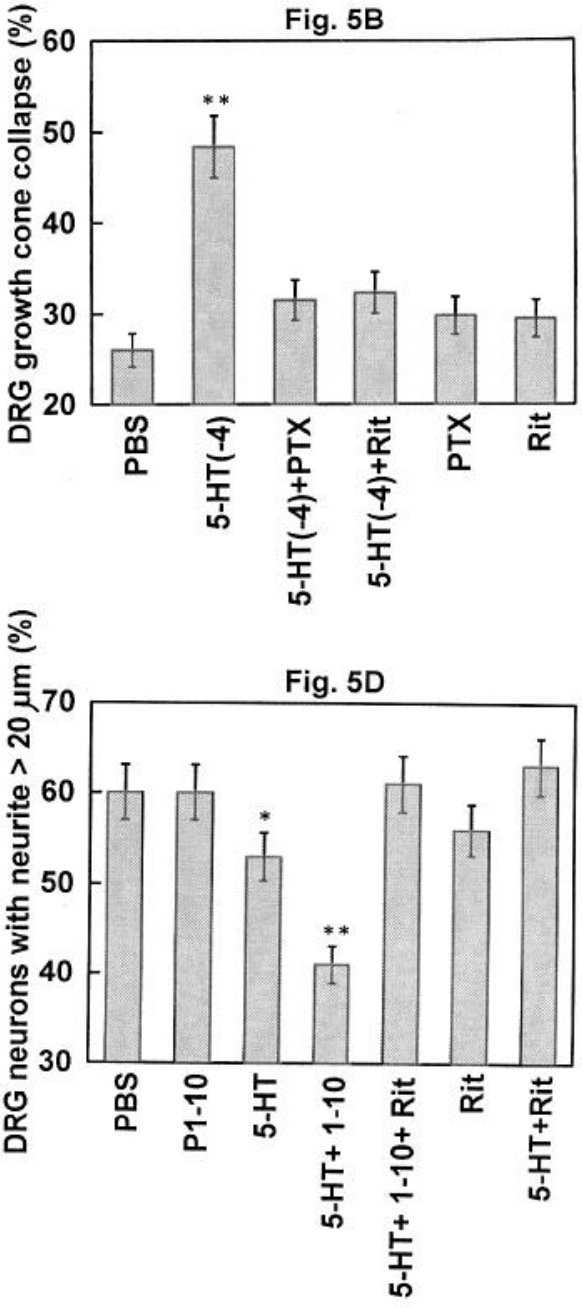

Figure 5. 5-HT-induced growth cone collapse is potentiated by GAP-43 110 peptide. $A$, Growth cone collapsed is enhanced by 5-HT in a dose-dependent manner ( $\boldsymbol{\square})$. The GAP-43 1-10 peptide $\left(10^{-8} \mathrm{M} ;-\right)$ acts synergistically with 5-HT. $B, 5$-HT-induced collapsed $\left(10^{-4} \mathrm{M}\right)$ is blocked by pertussis toxin $(P T X, 200 \mathrm{ng} / \mathrm{ml})$ and by ritanserin (Rit, $\left.10^{-4}\right)($ PBS, control; -4 means $\left.10^{-4}\right)$. $C$, The potentiation of 5-HT-induced collapse by the peptide is blocked by PTX and Rit. 5-HT by itself at $10^{-5} \mathrm{M}$ does not cause significant collapse. $D$, Neurite growth is inhibited by 5 -HT. GAP-43 P1-10 potentiates 5-HT-induced neurite inhibition. Ritanserin blocks the 5-HT effect. The values shown are the means \pm SEM for four separate experiments. ${ }^{*}, p<$ $0.05 ; * *, p<0.01$ ( $t$ test, vs PBS).
Peptides corresponding to the amino terminus stimulate isolated $G_{o}$, although less effectively than does native GAP-43 (Strittmatter et al., 1990). Palmitoylation of either the peptide or the native protein blocks $\mathrm{G}_{\mathrm{o}}$ stimulation. Thus, palmitoylated GAP-43 is far less active than is depalmitoylated GAP-43 (Sudo et al., 1992). Palmitoylation is a dynamic process, with a short half-life, unlike other types of acylation, which last for the duration of the protein. Whether the peptides contain a sequence adequate to serve as a palmitoylation substrate is unknown.

\section{$G_{o}$ and growth cone collapse}

The cell culture assay of growth cone collapse is very useful since it undoubtedly identifies growth-inhibitory signals, and, in all likelihood, other guidance or remodeling cues, and is likely to represent ligand-activated nerve terminal stimulation. It has been useful in identifying cell surface activities associated with myelin (Caroni and Schwab, 1988) and brain membranes (Raper and Kapfhammer, 1990), and used in their partial (Raper and Kapfhammer, 1990) or complete (Luo et al., 1993) purification. Some of the effects of the cell surface-associated collapsing activities of both myelin and brain membranes are inhibited by pertussis toxin (Igarashi et al., 1993), although there are clearly pertussis toxin-insensitive components as well (Igarashi et al., 1993). With myelin, it appears that G-protein stimulation causes release of calcium from intracellular stores (Bandtlow et al., 1993).

The most likely candidate $G$ protein to be linked to these receptors is $G_{o}$, because it is enriched in growth cones (Strittmatter et al., 1990) and is pertussis toxin sensitive. Single filopodial contact with targets can cause collapse of the entire growth cone. This implies a recognition and amplification of signals, either or both of which functions might be served by G-protein-coupled receptors. Soluble ligands also can cause collapse (Pini, 1993). Since serotonin, a G protein-coupled receptor, exerts this function in other organisms (Haydon et al., 1984; Davenport et al., 1993) and DRG bear 5-HT receptors (Todorovic and Anderson, 1990), we have examined 5-HT as a defined soluble ligand, and found it causes growth cone collapse, which is blocked by $5-\mathrm{HT}_{2}$ receptors. Thus, our interpretation is that GAP-43 serves to amplify a variety of guidance signals from growth cones. We have examined inhibitory signals here, but positive signals conceivably might also be affected, depending upon the cell.

This amplification function would also be compatible with a role in ligand-stimulated secretion at mature synapses, another documented GAP-43 effect (Dekker et al., 1989), and with changes in cell shape, assuming that there was a basal stimulation of cells, since G-protein activity affects these phenomena 

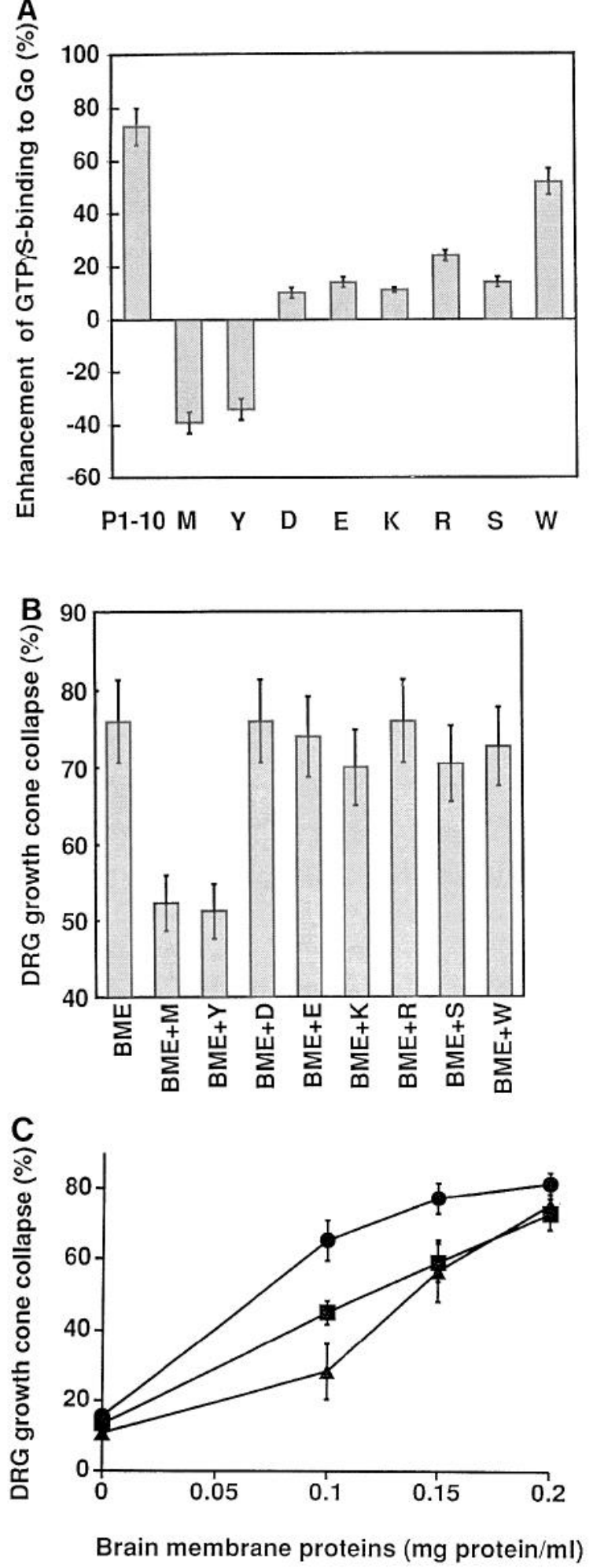

Figure 6. A, The effect of mutant decapeptides upon GTP $\gamma$ S-binding to $\mathrm{G}_{0}$. In each case, the single letter indicates the amino acid substituted for $\mathrm{Cys}^{3}$ and $\mathrm{Cys}^{4}$. The concentration of each peptide was $250 \mu \mathrm{M}$. The activity of GTP $\gamma$ S-binding to $G_{0}$ protein without peptides is shown as $100 \%$. The sequence of native N-terminus decapeptide of rat GAP-43 (1-10 peptide) is MLCCMRRTKQ. Both cysteine residues at positions 3 and 4 in the native $1-10$ peptide were replaced by methionine (M), tyrosine $(Y)$, aspartate $(D)$, glutamate $(E)$, lysine $(K)$, arginine $(R)$, serine $(S)$, or tryptophan $(W)$. The values shown are the means \pm SEM for three separate experiments. $B$, Brain membrane extract-induced growth cone collapse of DRG neurons is enhanced by two mutant peptides.
(Strittmatter et al., 1994b). It is not clear whether the PKC target serine or calmodulin binding of GAP-43 interact directly or indirectly with G-protein stimulation. For example, although the cell shape effects of GAP-43 can be exerted independently of the serine (Strittmatter et al., 1994b), substitution of different amino acids for serine $\mathrm{Ser}^{41}$ clearly modifies the effect (Widmer and Caroni, 1993). The two domains may interact.

\section{Intracellular targets}

GAP-43 is intracellular, as is $\mathrm{G}_{\mathrm{o}}$. Proof of intracellular site of action cannot depend upon direct labeling of the peptide, because its small size precludes confidence that addition of a labeling moiety leaves it comparably active and permeant. We previously suggested that the peptides gain intracellular access because longer peptides from the amino terminus are without effect unless the cell is first permeabilized (Strittmatter et al., 1994a). Here, we show directly that intracellular application of the peptide is not only effective, but actually more so than extracellular, as expected for intracellular action. Other peptides with intracellular targets have been noted to affect neurite growth (Igarashi et al., 1993; Higashijima et al., 1988; BlochGallego et al., 1993). How these peptides enter cells and via what compartment is unknown, but they are of special interest because of their potential therapeutic applications with regard to regeneration.

\section{Overcoming growth inhibition}

Repression of neurite outgrowth clearly is of critical importance to the developing nervous system in shaping borders and choosing pathways and partners. Responsible ligands are likely to include members of the semaphorin gene family identified in Drosophila, grasshopper, and human (Kolodkin et al., 1993). One growth collapsing ligand, collapsin, a member of this family, has been identified after biochemical isolation from embryonic brain, based on collapsing activity (Luo et al., 1993). It is likely that there are other inhibitory signals (Clarke and Moss, 1994).

With regard to CNS regeneration, it is clear that adult nerves can grow, but that they are prevented from doing so in the adult mammalian CNS by inhibitory substances (David and Aguayo, 1981). Intracellular targets may provide a useful therapeutic target in this regard. Although there may be a host of different receptors that retard growth, many might utilize similar intracellular cascades. Along these lines, $G_{o}$ is widespread in the brain (Worley et al., 1986), the response to different inhibitory ligands is pertussis toxin sensitive (Igarashi et al., 1993), $G_{o}$ activation modulates neurite growth from several cell types, and both CNS and PNS neurons respond to GAP-43 peptides (Igarashi et al., 1993). Since the native GAP-43 sequence amplifies inhibitory signals, we reasoned that changes in the sequence might permit the peptides to interact at the same site but to block activation of the pathway, and this turned out to be true for the

$\leftarrow$

The concentration of BME was $0.15 \mathrm{mg}$ protein $/ \mathrm{ml}$. One hour prior to addition of BME to DRG culture medium, each peptide was added at a concentration of $10^{-4} \mathrm{M}$. Note that peptide-M and peptide- $Y$, which attenuate GTP $\gamma$ S-binding to $G_{o}$, also attenuate the effect of BME. The values shown are the means \pm SEM for four separate experiments. $C$, Dose-response curves of BME versus DRG growth cone collapse in the absence of peptides $(-)$ and in the presence of $10^{-6} \mathrm{M} \mathrm{M}-(\square)$ and $10^{-6}$ M Y-substituted peptides $(\boldsymbol{\Delta})$. Solutions of peptides were prepared in PBS just prior to use. The values shown are the means \pm SEM for five separate experiments. 
tyrosine and methionine substitutions for cysteine, but not for other substitutions at those residues. We focused upon the cysteines because their normal posttranslational modification, as well as oxidation, markedly changes the peptide's $G_{0}$ stimulatory ability (Sudo et al., 1992). Since only the peptides with methione or tyrosine substitutions reduced the response to inhibitory ligands, and these peptides were the only two to inhibit rather than stimulate $G_{0}$, it is clear that it is via $G_{0}$ that their effect is exerted, although whether directly on $\mathrm{G}_{0}$ or by changing the effectiveness of receptor $-G_{0}$ interactions is not certain. The effect is only severalfold, which may not suffice in vivo. However, these peptides represent a start in the direction of discovery of new types of therapeutics for nerve regeneration.

\section{GAP-43 and plasticity}

The nerve terminal remodels throughout life, expanding and contracting when viewed in real time (Purves et al., 1987), and changing its structure and function as an accompaniment to long-term learning and memory (Greenough et al., 1986; Bailey and Chen, 1988). In many cases, these changes depend upon patterned electrical activity, appropriately timed in the pre- and postsynaptic cell. One dilemma raised by ongoing nerve growth is how to coordinate it with precision of connectivity. GAP-43 has been widely speculated to be instrumental in nerve growth and plasticity (Benowitz and Routtenberg, 1987; Fishman, 1989; Skene, 1989). Its action as an amplifier of signals would be compatible with this role, and also would solve this dilemma of plasticity versus precision. GAP-43 levels, and its activity as regulated by palmitoylation (Sudo et al., 1992) could set the neurons' responsiveness to signals from pathways or targets, signals that serve to enhance or retard growth by stimulating receptors on the nerve terminal. Thus, plasticity would work within constraints of precision. This model predicts that nerve growth would occur in animals lacking GAP-43, but might become aberrant at decision points, such as the midline. In fact, we have recently (Strittmatter et al., 1995) shown that nerves in GAP-43 mutant mice extend axons that have difficulty navigating the optic chiasm.

\section{References}

Alexander KA, Cimler BM, Meiri KE, Storm DR (1987) Regulation of calmodulin binding to P-57. J Biol Chem 262:6108-6113.

Bailey CH, Chen M (1988) Long-term sensitization in Aplysia increases the number of presynaptic contacts onto the identified gill motor neuron L7. Proc Natl Acad Sci USA 85:9356-9359.

Bandtlow CE, Schmidt MF, Hassinger TD, Kater SB, Schwab ME (1993) Role of intracellular calcium in NI-35-evoked collapse of neuronal growth cones. Science 259:80-83.

Benowitz LI. Routtenberg A (1987) A membrane phosphoprotein associated with neural development, axonal regeneration, phospholipid metabolism, and synaptic plasticity. Trends Neurosci 10:527.

Benowitz LI, Apostolides PJ, Perrone-Bizzozero N, Finklestein SP, Zwiers $H$ (1988) Anatomical distribution of the growth-associated protein GAP-43/B-50 in the adult rat brain. J Neurosci 8:339-352.

Bloch-Gallego E, Le Roux I, Joliot AII, Ilenderson CE, Prochiantz A (1993) Antennapedia homeobox peptide enhances growth and branching of embryonic chicken motoneurons in vitro. J Cell Biol 120:485-492.

Caroni P, Schwab ME (1988) Two membrane protein fractions from rat central myelin with inhibitory properties for neurite growth and fibroblast spreading. J Cell Biol 106:1281-1288.

Clarke GA, Moss DJ (1994) Identification of a novel protein from adult chicken brain that inhibits neurite outgrowth. J Cell Sci 107:33933402 .

Cox EC, Muller B, Bonhoeffer F (1990) Axonal growth in the chick visual system: posterior tectal membranes induce collapse of growth cones from the temporal retina. Neuron 4:31-37.
Davenport RW, Dou P, Rehder V, Kater SB (1993) A sensory role for neuronal growth cone filopodia. Nature 361:721-724.

David S, Aguayo AJ (1981) Axonal elongation into peripheral nervous system "bridges" after central nervous system injury in adult rats. Science 214:931-933.

Davies JA, Cook GMW, Stern CD, Keynes RJ (1990) Isolation from chick somites of a glycoprotein fraction that causes collapse of dorsal root ganglion growth cones. Neuron 4:11-20.

de la Monte SM, Federoff HJ, Ng SC, Grabczyk E, Fishman MC (1989) GAP-43 gene expression during development: persistence in a distinctive set of neurons in the mature central nervous system. Dev Brain Res. 46:161-168.

Dekker LV, De Graan PNE, Oestreicher AB, Versteeg DHG, Gispen WH (1989) Inhibition of noradrenaline release by antibodies to B-50. Nature 342:74-76.

Fishman MC (1989) Genes of neuronal growth and plasticity. In: Assembly of the nervous system (Landmesser L, ed), pp 247-257. New York: Liss.

Gispen WH, Van Dongen $\mathrm{CJ}$, De Graan PNE, Oestreicher AB, Zwiers $\mathrm{H}$ (1985) The role of phosphoprotein B-50 in phosphoinositide metabolism in brain synaptic plasma membranes. Inositol Phosphoinositides 399-413.

Greenough WT, McDonald JW, Parnisari RM, Camel JE (1986) Environmental conditions modulate degeneration and new dendrite growth in cerebellum of senescent rats. Brain Res 380:136-143.

Haydon PG, McCobb DP, Kater SB (1984) Serotonin selectively inhibits growth cone motility and synaptogenesis of specific identified neurons. Science 226:561-564.

Higashijima T, Burnier J, Ross EM (1990) Regulation of $G_{i}$ and $G_{0}$ by mastoparan, related amphiphlic peptides, and hydrophobic amines. Mechanism and structural determinants of activity. J Biol Chem 265 : 14176-14186.

Igarashi M, Strittmatter SM, Vartanian T, Fishman MC (1993) Mediation by $\mathrm{G}$ proteins of signals that cause collapse of growth cones. Science 259:77-79.

Ivgy-May N, Tamir H, Gershon MD (1994) Synaptic properties of serotonergic growth cones in developing rat brain. J Neurosci 14: 1011-1029.

Johnson AR (1993) Contact inhibition in the failure of mammalian CNS axonal regeneration. Bioessays 15:807-813.

Kennedy T, Serafini T, de la Torre J, Tessier-Lavine M (1994) Netrins are diffusable chemotropic factors for commissural axons in the embryonic spinal cord. Cell 78:425-435.

Keynes RJ, Cook GMW (1992) Repellent cues in axon guidance. Curr Opin Neurobiol 2:55-59.

Kolodkin AL, Matthes DJ, Goodman CS (1993) The semaphorin genes encode a family of transmembrane and secreted growth cone guidance molecules. Cell 75:1389-1399.

LaBate ME, Skene JHP (1989) Selective conservation of GAP-43 structure in vertebrate evolution. Neuron 3:299-310.

Leysen LE, Gommeren W, van Gompel P, Janssen PPM, Laduron PM (1986) Receptor-binding properties in vitro and in vivo of ritanserin: a very potent and long acting serotonin- $\mathrm{S}_{2}$ antagonist. Mol Pharmacol 27:600-611.

Luo Y, Raible D, Raper JA (1993) Collapsin: a protein in brain that induces the collapse and paralysis of neuronal growth cones. Cell 75 : 217-227.

McMahon AP, Bradley A (1990) The Wnt-1 (int-1) proto-oncogene is required for development of a large region of the mouse brain. Cell 62:1073-1085

Meiri KF, Gordon-Weeks PR (1990) GAP-43 in growth cones is associated with areas of membrane that are tightly bound to substrate and is a component of a membrane skelcton subccllular fraction. $J$ Neurosci 10:256-266.

Nielander HB, French P, Oestreicher AB, Gispen WH, Schotman P (1993) Spontaneous morphological changes by overexpression of the growth-associated protein B-50/GAP-43 in a PC12 cell line. Neurosci Lett 162:46-50.

Peter N, Aronoff B, Schacher S (1994) Decrease in growth cone-neurite fasciculation by sensory or motor cells in vitro accompanies down regulation of Aplysia cell adhesion molecules by neurotransmitters. J Neurosci 14:1413-1421.

Pini A (1993) Chemorepulsion of axons in the developing mammalian central nervous system. Science 261:95-98.

Purves D, Voyvodic JT, Magrassi L, Yawo H (1987) Nerve terminal 
remodeling visualized in living mice by repeated examination of the same neuron. Science 238:1122 1126.

Ramon y Cajal S (1990) New ideas on the structure of the nervous system in man and vertebrate. Cambridge, MA: MIT Press.

Raper JA, Kapfhammer JP (1990) The enrichment of a neuronal growth cone collapsing activity from embryonic chick brain. Neuron $4: 21-29$.

Skene JHP (1989) Axonal growth-associated proteins. Annu Rev Neurosci 12:127-156.

Skene JHP, Willard M (1981) Axonally transported proteins associated with axon growth in rabbit central and peripheral nervous system. $\mathbf{J}$ Cell Biol 89:96-103.

Strittmatter SM, Fishman MC (1991) The neuronal growth cone as a specialized transduction system. Bioessays 13:127-134.

Strittmatter SM, Valenzuela D, Kennedy TE, Neer EJ, Fishman MC (1990) $\mathbf{G}_{\mathrm{v}}$ is a major growth cone protein subject to regulation by GAP-43. Nature 344:836-841.

Strittmatter SM, Valenzuela D, Sudo Y, Linder ME, Fishman MC (1991) An intracellular guanine nucleotide release protein for $G_{0}$ : GAP-43 stimulates isolated $\alpha$ subunits by a novel mechanism. J Biol Chem 266:22465-22471.

Strittmatter SM, Cannon SC, Ross EM, Higashijima T, Fishman MC (1993) GAP-43 augments G protein-coupled receptor transduction in X. laevis oocytes. Proc Natl Acad Sci USA 90:5327-5331.

Strittmatter SM, Igarashi M, Fishman MC (1994a) GAP-43 amino terminal peptides modulate growth cone morphology and neurite outgrowth. J Neurosci 14:5503-5513.
Strittmatter SM, Valenzuela D, Fishman MC (1994b) An amino terminal domain of the growth-associated protein GAP-43 mediates its effects on filopodial formation and cell spreading. J Cell Sci 107: 195-204.

Strittmatter SM, Fankhauser C, Huang PL, Mashimo H, Fishman MC (1995) Neuronal pathfinding is abnormal in mice lacking the neuronal growth cone protein GAP-43. Cell 80:445-452.

Sudo Y, Valenzuela D, Beck-Sickinger AG, Fishman MC, Strittmatter SM (1992) Palmitoylation alters protein activity: blockade of $G_{0}$ stimulation by GAP-43. EMBO .I 11:2095-2102.

Todorovic S, Anderson EG (1990) 5- $\mathrm{HT}_{2}$ and 5- $\mathrm{HT}_{3}$ receptors mediate two distinct depolarizing responses in rat dorsal root ganglion neurons. Brain Res 511:71-79.

Widmer F, Caroni P (1993) Phosphorylation-site mutagenesis of the growth-associated protein GAP-43 modulates its effects on cell spreading and morphology. J Cell Biol 120:503-512.

Worley PF, Baraban JM, Van Dop C, Neer EJ, Synder SH (1986) $G_{0}$ a guanine nucleotide-binding protein: immunohistochemical localization in rat brain resembles distribution of second messenger systems. Proc Natl Acad Sci USA 83:4561-4565.

Zuber MX, Goodman DW, Karns LR, Fishman MC (1989a) The neuronal growth-associated protein GAP-43 induces filopodia in nonneuronal cells. Science 244:1193-1195.

Zuber MX, Strittmatter SM, Fishman MC (1989b) A membrane-targeting signal in the amino terminus of the neuronal protein GAP-43. Nature 341:345-348. 